\title{
Intra coronary freshly isolated bone marrow cells transplantation improve cardiac function in patients with ischemic heart disease
}

\author{
Ilkay Bozdag-Turan ${ }^{1 \dagger}$, R. Goekmen Turan ${ }^{1 *}$, Sophie Ludovicy ${ }^{1}$, Ibrahim Akin ${ }^{1}$, Stephan Kische ${ }^{1}$, Henrik Schneider ${ }^{1}$, \\ Tim C Rehders ${ }^{1}$, C Hakan Turan' ${ }^{1}$ Nicole S Arsoy' ${ }^{1}$ Tina Hermann ${ }^{1}$, Liliya Paranskaya', Jasmin Ortak1, \\ Peter Kohlschein ${ }^{2}$, Manuela Bastian², Kurtulus Sahin ${ }^{3}$, Christoph A Nienaber ${ }^{1}$ and Hueseyin Ince ${ }^{1}$
}

\begin{abstract}
Background: Autologous bone marrow cell transplantation (BMCs-Tx) is a promising novel option for treatment of cardiovascular disease. In this study we analyzed whether intracoronary autologous freshly isolated BMCs-Tx have beneficial effects on cardiac function in patients with ischemic heart disease (IHD).

Results: In this prospective nonrandomized study we treated 12 patients with IHD by freshly isolated BMCs-Tx by use of point of care system and compared them with a representative 12 control group without cell therapy. Global ejection fraction (EF) and infarct size area were determined by left ventriculography.

Intracoronary transplantation of autologous freshly isolated BMCs led to a significant reduction of infarct size $(p<0.001)$ and an increase of global EF $(p=0.003)$ as well as infarct wall movement velocity $(p<0.001)$ after 6 months follow-up compared to control group. In control group there were no significant differences of global EF, infarct size and infarct wall movement velocity between baseline and 6 months after coronary angiography. Furthermore, we found significant decrease in New York Heart Association (NYHA) as well as significant decrease of B-type natriuretic peptide (BNP) level 6 months after intracoronary cell therapy $(p<0.001)$, whereas there were no significant differences in control group 6 months after coronary angiography.
\end{abstract}

Conclusions: These results demonstrate that intracoronary transplantation of autologous freshly isolated BMCs by use of point of care system is safe and may lead to improvement of cardiac function in patients with IHD.

Trial registration: Registration number: ISRCTN54510226

Keywords: Ischemic heart disease, Freshly isolated bone marrow cell transplantation, Global EF, Infarct size

\section{Background}

Cardiac performance after myocardial infarction is compromised by ventricular remodelling, which represents a major cause of late infarct-related chronic heart failure and death [1-2]. Although conventional drug therapy may delay remodelling, there is no basic therapeutic regimen available for preventing or even reversing this process. By the use of interventional therapeutics, recanalization of the occluded infarct-related artery is possible, thereby improving or

\footnotetext{
*Correspondence: dr_g_turan@hotmail.com

†Equal contributors

'Department of Internal Medicine, Division of Cardiology, Rostock-University, Ernst Hydemann Str 6, Rostock 18055, Germany

Full list of author information is available at the end of the article
}

normalizing coronary blood flow. However, despite sufficient reperfusion of infracted tissue, the viability of the infracted myocardium cannot, or can only insufficiently, be improved in most of these patients [3]. Cell therapy is a promising novel option to improve vascularization or cardiac regeneration [4]. In animal models, bone marrowderived stem/progenitor cell infusion improves cardiac function and neovascularization after myocardial infarction [5-9]. Additionally, clinical trials indicate a benefical effect of intra coronary infusion of BMCs or circulating progenitor cells (CPCs) on myocardial function in patients with acute myocardial infarction (AMI) [10-14]. It is unknown whether freshly isolated BMCs transplantation have beneficially affects postinfarction remodelling. In this

\section{Biomed Central}


prospective nonrandomized control trial, we analyzed the influence of intracoronary freshly isolated cell therapy by use of point of care system on cardiac function in patients with ischemic heart disease (IHD).

\section{Methods \\ Patients}

In a prospective nonrandomized controlled trial, patients between 18-80 years of age were eligible for inclusion in this study if they had had a documented STEMI (ST-Elevation myocardial infarction) on ECG at least 3 months and had a clear-cut demarcated region of left ventricular dysfunction with an open infarct-related coronary artery at the time of stem cell therapy. Exclusion criteria were the presence of acutely decompensated heart failure with a New York Heart Association (NYHA) class of IV, infectious or inflammatory disease, active bleeding, surgery or trauma within 2 months, renal or liver dysfunction, thrombocytopenia, or anemia, alcohol or drug dependency, a history of other severe chronic diseases or cancer, or unwillingness to participate. The local ethics committee of University Rostock approved the study protocol. All the participants have given their written informed consent. All IHD patients were discharged with standard medication consisting of acetylsalicylic acid and/or clopidogrel, an ACE inhibitor, a ß-blocker and a statin.

\section{Study protocol}

24 IHD patients were enrolled in this prospective nonrandomized controlled study. 12 of them underwent intracoronary transplantation of autologous freshly isolated BMCs by use of point of care system whereas 12 patients served as a control group who received only coronary angiography and left ventriculography without any cell based therapy. We performed in all patients of both groups before cell transplantation a coronary angiography as well as a left ventriculography and presented with open infarct-related coronary arteries. Patients included in the cell therapy group underwent a bone marrow puncture and BM aspiration on day 1 after admission. BMCs were separated. Subsequently, after coronary angiography and left ventriculography, the BMCs were freshly transplanted intracoronary. The primary end point of the study was the change in global EF as well as the size of infarcted area measured by left ventriculography after 6 months. Secondary end point was the functional status by NYHA classification and B-type natriuretic peptide (BNP) level in peripheral blood (PB) in both groups. All data were obtained by blinded expert readers unaware of patient group assignment.

\section{Preparation and administrations of BMC}

A total of approximately $120 \mathrm{ml}$ of bone marrow was aspirated from the iliac crest after local anaesthesia and mononuclear cells were isolated and identified including
$\mathrm{CD}_{4} 4^{+}$and $\mathrm{CD}_{133^{+}}$. The bone marrow cell concentrate suspension was isolated using the Harvest BMAC System (Harvest Technologies $\mathrm{GmbH}$, Munich, Germany) according to the manufactures instructions for use to produce $20 \mathrm{mls}$ of concentrated cells. The concentrate consisted of a heterogeneous cell population including hematopoietic, mesenchymal, other progenitor cells as well as granulocytes and platelets.

After undergoing arterial puncture, all patients received 7500 to 10000 Units of heparin. Cell transplantation was performed via the intracoronary administration route [15] using four to six fractional infusions parallel to balloon inflation over 2 to $4 \mathrm{~min}$ of 3 to $5 \mathrm{ml}$ of cell suspension. All cells were infused directly into the infarcted zone through the infarct related artery via an angioplasty balloon catheter, which was inflated at a low pressure (4 to 8 atm) and was located within the previously stented coronary segments. This prevented back flow of cells and produced stop flow beyond the site of balloon inflation to facilitate high-pressure infiltration of cells into the infarcted zone with prolonged contact time for cellular migration. 6 months after catheter-guided cell transplantation, all functional tests were repeated, including coronary angiography and left ventriculography. There were no procedural or cell-induced complications and there were no side effects in any patients.

\section{Coronary angiography and left ventriculography}

Patients in both groups underwent left heart catheterization, left ventriculography and coronary angiography. Cardiac function, End-diastolic volume (LVEDV), End-systolic volume (LVESV), Stroke volume index (SVI) and infarct size were determined by left ventriculography. Left ventriculography was performed for each patients in 2 projections LAO 30/0 and RAO $50 / 0^{\circ}$. Cardiac function was evaluated by global EF and by auxotonic myocardial contractility index, evaluated by the wall movement velocity of the infarcted area. Global EF was measured with Quantcor software (Siemens, Erlangen/Germany). To quantify the size of infarct area we used the centreline method according to Sheehan [16] by plotting five axes perpendicular to the long axis of the heart in the main akinetic or dyskinetic segment of ventricular wall. Systolic and diastolic lengths were then measured by two blinded independent observers, and the mean difference was divided by systolic duration in seconds. The follow-up was 6 months after the treatment. All hemodynamic baseline and follow-up investigations and between the two groups were obtained in a blinded nonrandomized order by two independent observers/cardiologist. 


\section{Safety parameters}

To assess any inflammatory response and myocardial reaction after cell therapy, white blood cell count, the serum levels of $\mathrm{C}$-reactive protein (CRP) and of creatine kinase $(\mathrm{CK})$ were determined immediately before and after treatment. Additional analysis was done directly after transplantation and three months later: BNP level in PB, ECG at rest, 24-h Holter ECG and echocardiography. Procedural complications were defined as any ventricular arrythmia, visible thrombus formation, distal embolization, or injury of the coronary artery associated with the cell infusion catheterization procedure.

\section{Statistical analysis}

Quantitative data are presented with mean \pm SD and qualitative data are tabulated using absolute frequencies and/or percentages. Differences between therapy groups for qualitative variables were tested using Fisher's-ExactTest due to small number of patients in therapy groups. Within differences of quantitative variables in each therapy group are compared using the Wilcoxon-Test for depending samples, and differences between therapy groups of quantitative variables are compared with the Wilcoxon-Test (Mann-Whitney-Test) for independent samples. Both of those nonparametric Wilcoxon-Tests are prefered due to the more likely expected non-normal distribution of the data. For all statistical tests, a result will be seen as statistically significant, if the corresponding two-sided p-value is smaller or equal to 0.05 . If the mean and the median did not differ markedly for a variable, the graphical presentation of the data was be done using the mean and SD of this variable. Statistical analysis was performed with SPSS for Windows (Version 15.0)

\section{Results}

\section{Baseline characteristics of the patients}

12 patients in the intervention group received BMCs-Tx, whereas 12 patients in second group received no intra coronary BMCs-Tx and served as a control. There were no significant differences between the baseline characteristics and demographics of patients between both groups. Moreover there were also no significant differences in medical therapy at 3 and 6 months after procedure between both groups (Table 1)

\section{Cellular composition of point of care system from bone marrow cells}

Table 2 showed the cellular composition of bone marrow aspirate $(120 \mathrm{ml})$ and bone marrow concentrate $(20 \mathrm{ml})$ as well as viability of cells by use of point of care system. The number of cells of total nucleated cells, CD34 ${ }^{+}, \mathrm{CD}_{133^{+}}$ and platelets count increased significantly post seperation Table 1 Baseline clinical characteristics of patients with
ischemic heart disease with bone marrow cells
transplantation and control group without
transplantation

\begin{tabular}{llll}
\hline & $\begin{array}{l}\text { IHD with } \\
\text { BMCs-Tx } \\
(\mathbf{n}=12)\end{array}$ & $\begin{array}{l}\text { IHD without } \\
\text { BMCs-Tx } \\
(\mathbf{n}=12)\end{array}$ & P \\
\hline Age & $62 \pm 6$ & $60 \pm 5$ & NS \\
$\mathrm{m} / \mathrm{f}$ & $8 / 4$ & $9 / 3$ & NS
\end{tabular}

Cardiovascular Risk Factors (\%)

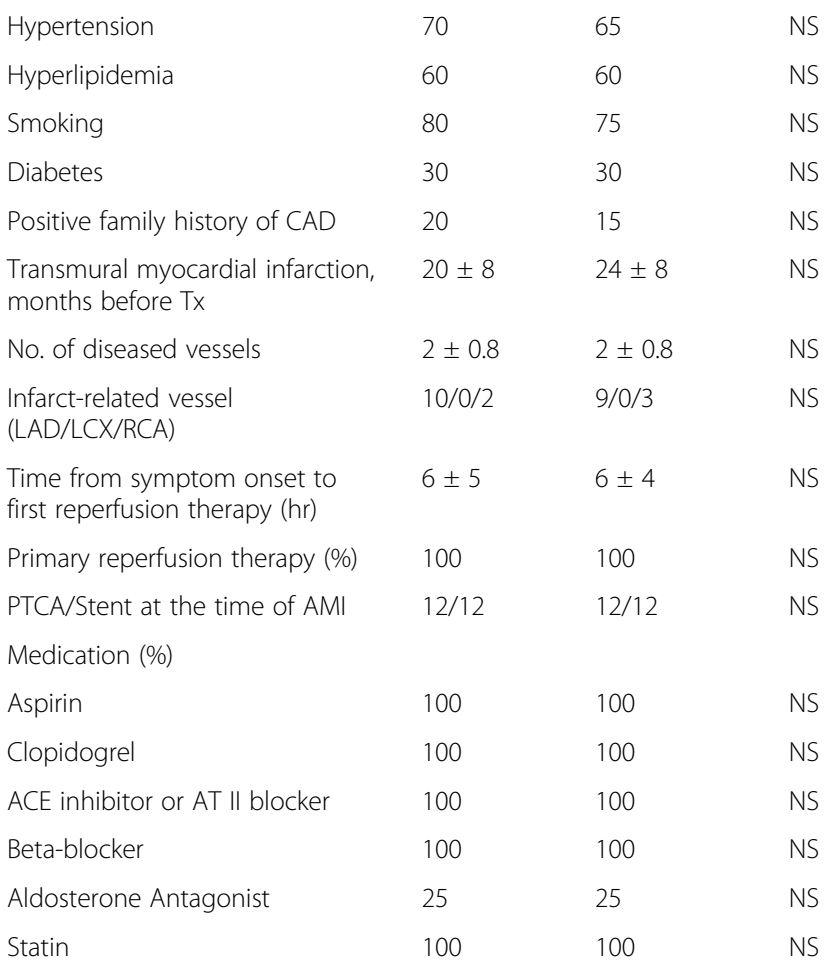

Laboratory parameters

$\begin{array}{lll}\text { CPK U/L } & 2010 \pm 540 \quad 2145 \pm 670 \quad \text { NS }\end{array}$

Ischemic heart disease (IHD), Bone marrow cells transplantation (BMCs-Tx), Coronary artery disease (CAD), Percutaneous transluminal coronary angioplasty (PTCA), Creatine phosphokinase (CPK), Left anterior descending coronary artery (LAD), Left circumflex artery (LCX), Right coronary artery (RCA), None significant (NS).

in bone marrow concentrate compared to pre seperation in bone marrow aspirate $(\mathrm{p}<0.001)$.

\section{Effect of freshly isolated BMCs transplantation Left ventricular function, infarct size and infarct wall movement velocity}

Global EF, LVEDV, LVESV, SVI, infarct size and the wall movement velocity of the infarcted area were measured by left ventriculography in the first group immediately before and 6 months after BMCs-Tx as well as in the second group without BMCs-Tx pre- and 6 months after cardiac catheterization. There were no significant baseline differences in global EF, LVEDV, LVESV, SVI, infarct size and 
Table 2 The Cellular Composition of Bone Marrow Aspirate and Bone Marrow Concentrate by use of point of care system in the group with BMCs-Tx

\begin{tabular}{lll}
\hline & $\begin{array}{l}\text { Bone Marrow } \\
\text { Aspirate } \\
\text { (Pre Separation, } \\
\mathbf{1 2 0} \mathbf{~ c c})\end{array}$ & $\begin{array}{l}\text { Bone Marrow } \\
\text { Concentrate } \\
\text { (Post Separation, } \\
\mathbf{2 0} \text { cc) }\end{array}$ \\
\hline Total nucleated cells $\left(\times 10^{6} \mathrm{ml}\right)$ & $28 \pm 8$ & $100 \pm 24$ \\
$\mathrm{CD}^{+} 4^{+}$cells $\left(\times 10^{6} \mathrm{ml}\right)$ & $0.25 \pm 0.08$ & $0.93 \pm 0.2$ \\
$\mathrm{CD}^{+} 33^{+}$cells $\left(\times 10^{6} \mathrm{ml}\right)$ & $0.07 \pm 0.006$ & $0.37 \pm 0.04$ \\
Platelet count $\left(\times 10^{3} / \mu \mathrm{l}\right)$ & $162 \pm 21$ & $697 \pm 159$ \\
Viability of cells $(\%)$ & $98 \pm 1.5$ & \\
\hline
\end{tabular}

infarct wall movement velocity between the two groups (Tables 3 and 4). 6 months after cell therapy, we observed a significant increase of global EF and infarct wall movement velocity compared to baseline. Furthermore, we found significant decrease of infarct size after 6 months compared to baseline (Table 3). Moreover, global EF and wall movement velocity of the infracted area significantly increased 6 months after cell therapy compared to control group (Figures 1 and 2). Infarct size significantly decreased 6 months after BMCs-Tx as compared to control group without cell therapy (Figure 3). Additionally we found a significant increase of SVI and decrease of LVESV whereas no significant change was observed in LVEDV 6 months after cell therapy (Table 3). In the control group there were no significant changes in global EF, LVEDV, LVESV, SVI, infarct size and the wall movement velocity of the infarcted area 6 months after coronary angiography (Table 4).

Table 3 Cardiac function, clinical parameter immediately pre- and 6 months after bone marrrow cells transplantation in the bone marrow cell transplantation group

\begin{tabular}{llll}
\hline & $\begin{array}{l}\text { Immediately pre } \\
\text { BMCs-Tx }\end{array}$ & $\begin{array}{l}\mathbf{6} \text { months after } \\
\text { BMCs-Tx }\end{array}$ & P \\
\hline Global EF (\%) & $42 \pm 8$ & $54 \pm 10$ & $\mathrm{p}=0.001$ \\
$\begin{array}{l}\text { The size of infarct } \\
\text { area (\%) }\end{array}$ & $33 \pm 10$ & $17 \pm 10$ & $\mathrm{p}<0.001$ \\
$\begin{array}{l}\text { Infarct wall movement } \\
\text { velocity (cm/s) }\end{array}$ & $1.70 \pm 0.90$ & $3.98 \pm 0.86$ & $\mathrm{p}<0.001$ \\
$\begin{array}{l}\text { End-diastolic volume } \\
\text { (LVEDV) (ml) }\end{array}$ & $128 \pm 45$ & $136 \pm 50$ & $\mathrm{p}=\mathrm{NS}$ \\
$\begin{array}{l}\text { End-systolic volume } \\
\text { (LVESV) (ml) }\end{array}$ & $74 \pm 25$ & $63 \pm 25$ & $\mathrm{p}<0.01$ \\
$\begin{array}{l}\text { Stroke volume index } \\
\text { (SVI) (ml/m²) }\end{array}$ & $30 \pm 10$ & $40 \pm 8$ & $\mathrm{p}<0.01$ \\
$\begin{array}{l}\text { BNP (pg/ml) } \\
\text { NYHA classification }\end{array}$ & $169 \pm 85$ & $72 \pm 21$ & $\mathrm{p}<0.001$ \\
\hline
\end{tabular}

\section{Functional status and clinical safety parameters}

To determine the functional status we assessed NYHA classification and BNP levels in both groups by two independent and blinded physicians. There were no significant differences of at baseline NYHA classification and BNP levels between both groups. We observed significant decrease in NYHA classification and BNP levels 6 months after intracoronary cell therapy, whereas there were no significant differences in control group 6 months after coronary angiography (Table 3 and 4). NYHA classification and BNP levels significantly decreased 6 months after cell therapy compared to control group (Figure 4).

ECG at rest, on exercise and 24-h Holter ECG revealed no rhythm disturbances. There was no inflammatory response or myocardial infarction (white blood cell count, CRP, CK) after cell therapy. No immediate periprocedure as well as postprocedure adverese complications and no new electrocardiographic changes or significant elevations in CK or troponin as well as no inflammatory response were observed in patients with BMC-Tx

\section{Discussion}

In this prospective nonrandomized controlled study we could demonstrate improved global EF, infarct size as well as functional status after intra coronary autologous freshly isolated bone marrow cells transplantation in patients with IHD.

Despite improved pharmacological therapy, congestive heart failure remains the leading cause of cardiovascular mortality in industrialized world [17]. The use of stem cell-

Table 4 Cardiac function, clinical parameter pre- and 6 months after coronary angiography in control group without bone marrrow cells transplantation

\begin{tabular}{|c|c|c|c|}
\hline & $\begin{array}{l}\text { Immediately } \\
\text { pre coronary } \\
\text { angiography }\end{array}$ & $\begin{array}{l}6 \text { months } \\
\text { after } \\
\text { coronary } \\
\text { angiogrpahy }\end{array}$ & $P$ \\
\hline Global EF (\%) & $43 \pm 10$ & $44 \pm 8$ & $\mathrm{p}=\mathrm{NS}$ \\
\hline $\begin{array}{l}\text { The size of } \\
\text { infarct area (\%) }\end{array}$ & $32 \pm 10$ & $30 \pm 10$ & $p=N S$ \\
\hline $\begin{array}{l}\text { Infarct wall } \\
\text { movement velocity } \\
(\mathrm{cm} / \mathrm{s})\end{array}$ & $1.76 \pm 0.76$ & $1.80 \pm 0.76$ & $\mathrm{p}=\mathrm{NS}$ \\
\hline $\begin{array}{l}\text { End-diastolic } \\
\text { volume } \\
\text { (LVEDV) (ml) }\end{array}$ & $132 \pm 35$ & $136 \pm 48$ & $\mathrm{p}=\mathrm{NS}$ \\
\hline $\begin{array}{l}\text { End-systolic volume } \\
\text { (LVESV) (ml) }\end{array}$ & $75 \pm 29$ & $76 \pm 29$ & $\mathrm{p}=\mathrm{NS}$ \\
\hline $\begin{array}{l}\text { Stroke volume index } \\
(\mathrm{SVl})\left(\mathrm{ml} / \mathrm{m}^{2}\right)\end{array}$ & $29 \pm 11$ & $33 \pm 15$ & $\mathrm{p}=\mathrm{NS}$ \\
\hline BNP (pg/ml) & $155 \pm 71$ & $141 \pm 69$ & $\mathrm{p}=\mathrm{NS}$ \\
\hline NYHA classification & $\|-\mid\|$ & $\|-\mid\|$ & $\mathrm{p}=\mathrm{NS}$ \\
\hline
\end{tabular}




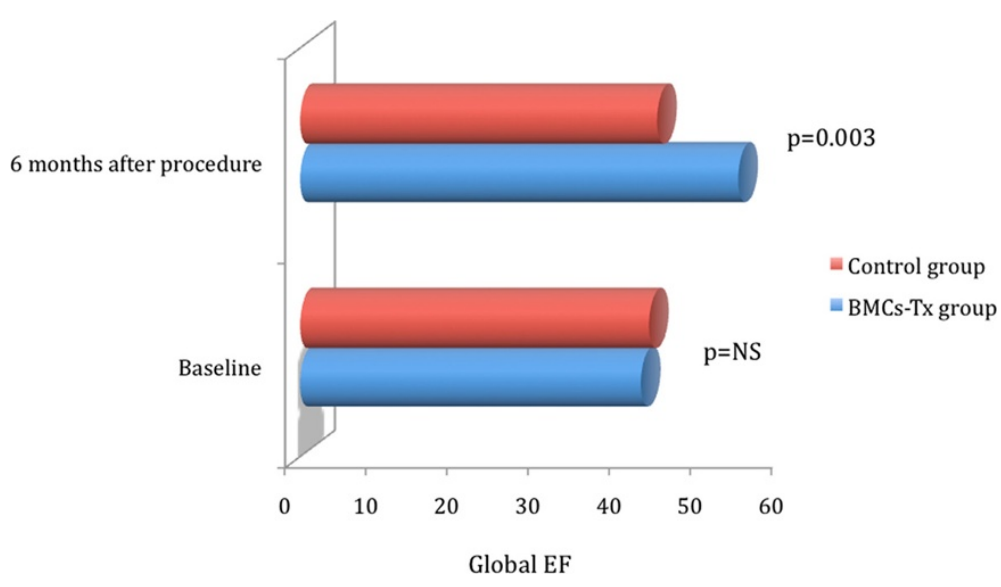

Figure 1 Global EF were measured by left ventriculography immediately pre and 6 months after procedure in both groups. There were no significant baseline differences in global EF between the two groups. Global EF significantly increased 6 months after cell therapy as compared to control group. Furthermore, no significant changes were observed in the control group at follow-up.

based therapy is becoming increasingly recognized as having the potential to salvage damaged myocardium and to promote endogenous repair of cardiac tissue, thus having the potential for the treatment of heart failure. Experimental studies demonstrated that intravascular or intramyocardial administration of BMCs or CPCs may contribute to functional regeneration of infarcted myocardium and enhance neovascularization of ischaemic myocardium [5-9]. Clinical pilot and randomized trials suggested, that the intracoronary infusion of autologous BMCs is safe and feasible as well as beneficially affects left ventricular contractile recovery and infarct size in patients with AMI [10-14]. The beneficial effects observed in most phase I/II studies were confirmed in the so far largest douple-blind, randomized multicenter
REPAIR-AMI trial [14]. Only one larger study, the ASTAMI trial [18] did not show any benefit on leftventricular functional parameters. The reason for the failure of the ASTAMI trial to show a benefit of cell therapy may have been the different cell isolation and storage protocol, which significantly affected the functional capacity of the cells [19]. Likewise, it was reported, that intracoronary infusion of BMCs in patients with ischemic heart disease improve moderate left ventricular function [20-21]. In our study, we demonstrated that the infarct size reduced, whereas the global EF and regional infarct wall movement velocity increased 6 months after intracoronary cell therapy in patients with IHD. This observation is in line with the data of Strauer et al [20]. and Assmus et al [21]. In

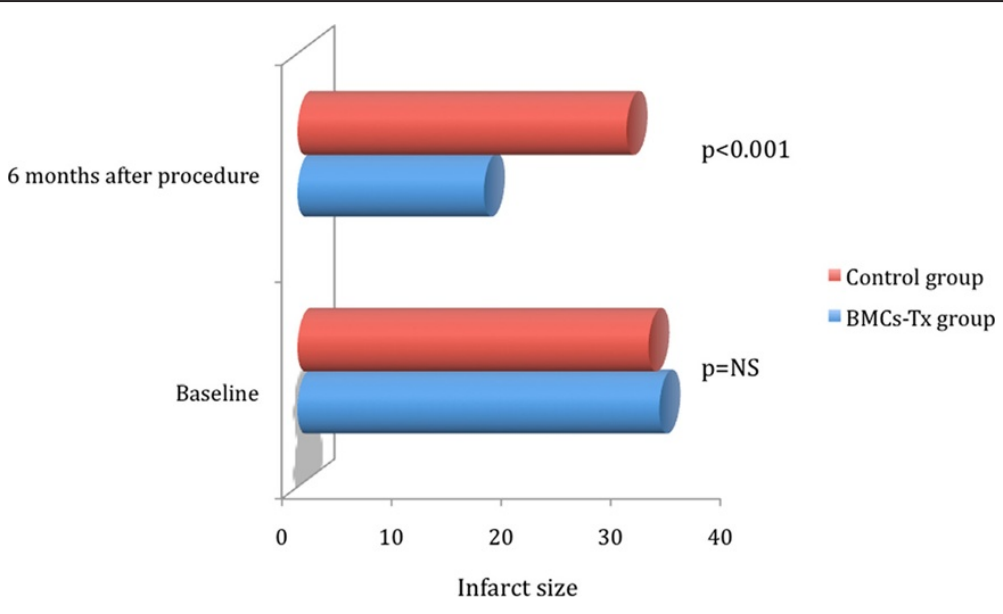

Figure 2 Infarct wall movement velocity were measured by left ventriculography immediately pre and 6 months after procedure in both groups. There were no significant baseline differences in infarct wall movement velocity between the two groups. infarct wall movement velocity significantly increased 6 months after cell therapy as compared to control group. Furthermore, no significant changes were observed in the control group at follow-up. 


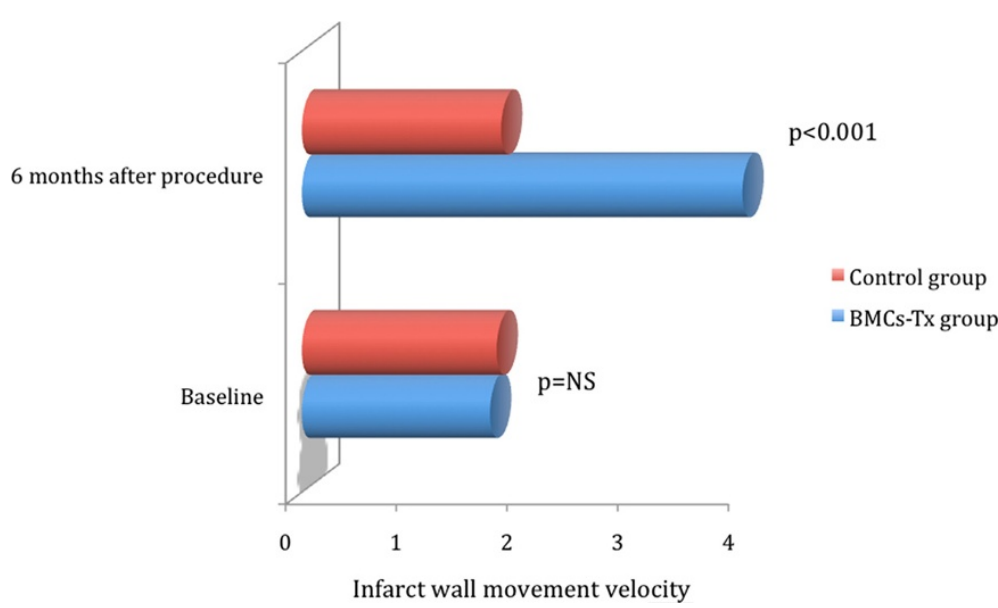

Figure 3 Infarct size were measured by left ventriculography immediately pre and 6 months after procedure in both groups. There were no significant baseline differences in infarct size between the two groups. There was a significant decrease of infarct size 6 months after cell transplantation compared to control group without cell therapy. Moreover, no significant changes were observed in the control group at followup.

a

6 months after procedure
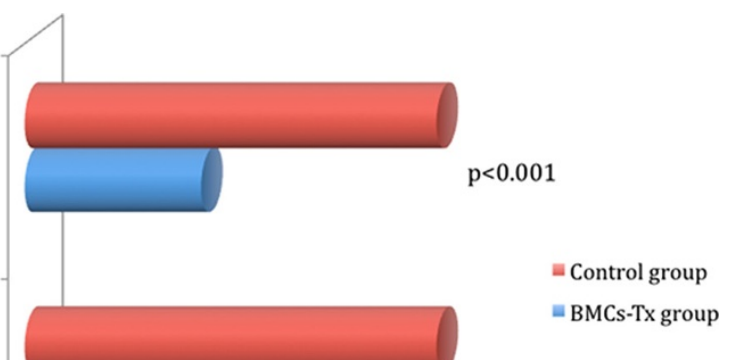

Baseline

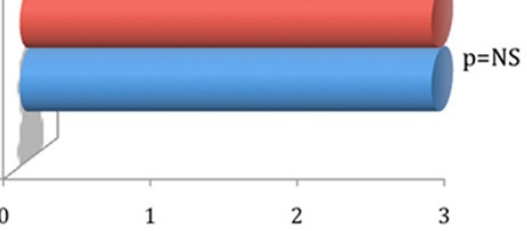

NYHA

b

6 months after procedure

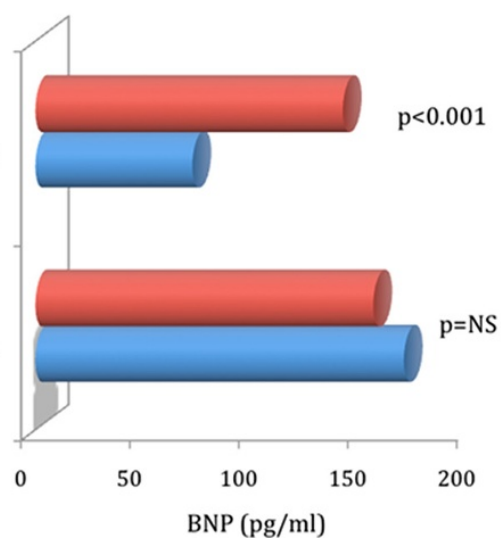

$=$ Control group

= BMCs-Tx group

$\mathrm{BNP}(\mathrm{pg} / \mathrm{ml})$

Figure 4 NYHA classification and BNP levels in both groups. There were no significant differences of baseline NYHA classification and BNP levels between two groups. 6 months after cell therapy there were a significant decrease of NYHA classification and BNP levels compared to control group without cell therapy. Moreover, no significant changes were observed in the control group at follow up. 
addition, we observed decrease in NYHA classification and BNP levels 6 months after cell therapy. Because most of the previous clinical trials involved BMCs isolated by Ficoll [10-14], this thecnique currently viewed as the gold standard. Cell isolation procedures are crucial for the functional activity of the administered cellular product. In our trial we chose to use a point of care system for the preparation of the treating cell composition. We showed in pilot study that freshly isolated BMCs-Tx by use a point of care system is safe and feasible as well as may improve the cardiac function also in patients after AMI [22]. Previous studies have demonstrated, that the mobilization and functional activity of CD34/45 and CD133/45 ${ }^{+}$BM-CPCs significantly increased after intracoronary infusion of BMCs in patients with ischemic heart disease [23-24]. We demonstrated the same results for the first time with intracoronary freshly isolated BMCs-Tx by use a point of care system in patients with IHD, not Ficoll gradient separation as in other studies. Unlike many previously conducted trials that employed Ficoll gradient separation as the method of cell collection, which produces a very limited cell linage spectrum. The cellular composition of the concentrate, which was prepared by use a point of care system, differs from that prepared using the Ficoll method. The Ficoll composition contains predominantly mononuclear cells (lymphocytes, erythroblasts and monocytes) and very few granulocytes. The point of care system concentrates entire nucleated cell population with mononuclear cells and specific stem cell population (CD34+ and CD133 + ) as well as the platelets from the marrow aspirate (Table 2). Importantly, however, the point of care device provided advantage of significantly higher yield of isolated bone marrow cells compared to the Ficoll protocol. Thus, if the number of infused cells in invivo neovascularization model was adjusted for this higher yield of bone marrow cells, the treatment effect was significantly greater compared to Ficoll BMCs, as assessed by limb perfusion measurement [25]. One obvious difference in the two compositions is the presence of significant numbers of granulocytes and platelets in the point of care system composition. Platelets and granulocytes have been shown to have a positive effect on the neovascular potential of the resulting concentrate. The presence of platelets within composition could be important because it has been shown that these platelet-derived mediators also potently enhance postnatal angiogenesis. Iba and colleagues demonstrated that implantation of mononuclear cells together with platelets into ischemic limbs more effectively augments collateral vessel formation by supplying various angiogenic factors, in which VEGF played a key role [26]. Indeed, Massberg and colleagues provided compel ling evidence that platelets generate the critical signal that recruits CD34+ bone marrow cells and c-Kit + Sca- $1+$ Lin- bone marrow-derived progenitor cells to sites of injury [27]. Therefore, these findings strongly support the notion that implanted platelets play a pivotal role in stem and progenitor recruitment and provide a rationale for the fact that point of care system produced functional in vivo results similar to or better than Ficoll. In our study despite higher number of platelets we observed no immediate periprocedure as well as postprocedure adverese complications. In addition, unlike Ficoll isolation where cells are resuspended in a serum free medium, point of care system is always resuspended in the patient's own plasma. Thus, the isolated cells are not removed from their natural plasma microenvironment, which may be help to sustain the functionality of the cells. This has been further supported by experimental study of Hermann et al., who showed that the point of care system composition to be significantly more bioactive than the Ficoll composition. Intriguingly, however, due to the greater yield of cells generated by use a point of care system, the cellular product isolated from a given bone marrow aspirate by use a point of care device may actually translate into even greater therapeutic effects. Additionally, practical aspects may also deserve consideration. Importantly, a major limitation of the Ficoll isolation procedure for clinical applications is that it is strongly investigator dependant, immensely time consuming and requires a good manufacturing practice (GMP) facility. In this study we were able to demonstrate that such complex methods are not necessary to achieve established results. As the concentration process by use of point of care system, everything can be accomplished in one session without adding excessive time to the overall procedure circumventing the previously mentioned disadvantages of the Ficoll isolation process. The point of care device provides a much shorter turnaround time. Therefore, this device represents a cost-effective and time-efficient standalone technique for the isolation of autologous bone marrow cells suitable for cell therapy regimens in the rapidly growing field of regenerative medicine.

Several hypotheses have been proposed about, how intracoronary cell therapy improves myocardial function. I) Experimental studies addressing the capacity of transplanted bone marrow-derived stem cells to differentiate into the cardiomyogenic lineage yielded conflicting results. Recent well-conducted studies suggest that the BMCs do not transdifferentiate into cardiomyocytes but adopt mature hematopoeitic characteristics. In contrast to embryonic stem cells, most adult stem or progenitor cells do not spontaneously differentiate into cardiomyocytes but rather require an adequate stimulus to do so. II) Another proposed mechanism is that cell therapy may increase angiogenesis and improve blood supply to ischemic regions, potentially aiding in the revascularization of hibernating myocardium and inhibiting cardiomyocyte apoptosis. Additionally or alternatively, the local microenvironment plays an important role to induce cell fate changes by physical cell-to-cell interaction or by providing paracrine factors promoting tissue repair [28-30]. 
Cell-based therapy is a promising option for treatment of ischemic disease. However, cell therapy is in its early stages, and various questions remain. BMCs are best characterized and have been used in the majority of clinical trials performed to date. BMCs contains a complex assortment of progenitor cells, including hematopoietic stem cells (HSCs), mesenchymal stem cells (MSCs) or stromal cells and multipotential adult progenitor cells (MAPCs) [31]. Additionally, The presence of immature circulating cells in the peripheral blood has been advocated as a marker of an organism `s regenerative capacity [32].

The primary limitation of this study is the only use of left ventriculography for cardiac function without the additionally measurement of cardiac imaging. However the same assessments was used in several studies [10, 14, 15, 20, 21]. Moreover, for better understanding we added left ventricular volume data in our study. Secondly the placebo effect on improvement of NYHA classification in cell therapy group can not be excluded due to the obvious. On the other hand this result was confirmed indirectly by decrease of BNP values in PB and improvement of global EF. Therefore, a randomized placebo-controlled study will be needed to validate the hypothesis.

\section{Conclusions}

In the present study we could demonstrate that intracoronary transplantation of autologous freshly isolated BMCs by point of care system improved global EF and reduced infarct size significantly in patients with IHD after 6 months. Moreover, we observed a significant decrease of NYHA-classification and BNP levels even 6 months after cell transplantation. This interesting observation could be implemented in future large-scale randomized studies.

\section{Abbreviations}

BMCs-Tx: Autologous freshly isolated bone marrow cells transplantation; IHD: Ischemic heart disease; EF: Ejection fraction; CPCs: Circulating progenitor cells; AMI: Acute myocardial infarction; NYHA: New York Heart Association; PB: Peripheral blood; BNP: B-type natriuretic peptide; LVEDV: End-diastolic volume; LVESV: End-systolic volume; SVI: Stroke volume index; CRP: C-reactive protein; CK: Creatine kinase.

\section{Competing Interest}

The authors declare that they have no competing interests.

\section{Acknowledgments}

This study was funded by Department of Internal Medicine, Division of Cardiology, University hospital Rostock, Germany.

\section{Author details}

${ }^{1}$ Department of Internal Medicine, Division of Cardiology, Rostock-University, Ernst Hydemann Str 6, Rostock 18055, Germany. ${ }^{2}$ Institute of Clinical Chemistry \& Laboratory Medicine, University of Rostock, Rostock Germany. ${ }^{3}$ Institute for Clinical Research and Statistics, Cologne Germany.

\section{Authors`Contributions}

All authors listed have contributed sufficiently to the project to be included as authors. All authors contributed to the acquisition and analysis/ interpretation of data, as well as the conception and design.

Received: 8 November 2011 Accepted: 5 April 2012

Published: 25 April 2012

\section{References}

1. Pfeffer MA, Braunwald: Ventricular remodelling after myocardial infarction. Experimental observations and clinical implications. Circulation 1990, 81:1161-1172.

2. Pfeffer AM: Left ventricular remodelling after acute myocardial infarction. Annu Rev Med 1995, 46:455-456.

3. Zijlstra F, de Boer M, Beukema W, Reiffers S, Huysmans D, Hoorntje JC, Suryapranata $\mathrm{H}$, Simoons ML: Mortality, reinfarction, left ventricular ejection fraction and costs following reperfusion therapies for acute myocardial infarction. Eur Heart J 1996, 17:382-389.

4. Perin EC, Geng YJ, Willerson JT: Adult stem cell therapy in perspective. Circulation 2003, 107:935-938.

5. Orlic D, Kajstura J, Chimenti S, Limana F, Jakoniuk I, Quaini F, Nadal-Ginard B, Bodine DM, Leri A, Anversa P: Mobilised bone marrow cells repair the infarcted heart, improving function and survival. Proc Natl Acad Sci USA 2001, 98:10344-10349.

6. Orlic D, Kajstura J, Chimenti S, Bodine DM, Leri A, Anversa P: Bone marrow cells regenerate infarcted myocardium. Nature 2001, 410:701-705.

7. Kocher AA, Schuster MD, Szabolcs MJ, Takuma S, Burkhoff D, Wang J, Homma S, Edwards NM, Itescu S: Neovascularization of ischaemic myocardium by human bone-marrow-derived angioblasts prevents cardiomyocyte apoptosis, reduces remodeling and improves cardiac function. Nat Med 2001, 7:430-436.

8. Fuchs S, Baffour R, Zhou YF, Shou M, Pierre A, Tio FO, Weissman NJ, Leon $M B$, Epstein SE, Kornowski R: Transendocardial delivery of autologous bone marrow enhances collateral perfusion and regional function in pigs with chronic experimental myocardial ischaemia. J Am Coll Cardiol 2001, 37:1726-1732.

9. Kawamoto A, Gwon HC, Iwaguro H, Yamaguchi Jl, Uchida S, Masuda H, Silver M, Ma H, Kearney M, Isner JM, Asahara T: Therapeutic potential of ex vivo expanded endothelial progenitor cells for myocardial ischemia. Circulation 2001, 103:634-637.

10. Assmus B, Schachinger $V$, Teupe $C$, Britten $M$, Lehmann R, Döbert N, Grünwald F, Aicher A, Urbich C, Martin H, Hoelzer D, Dimmeler S, Zeiher AM: Transplantation of progenitor cells and regeneration enhancement in acute myocardial infarction (TOPCARE-AMI). Circulation 2002, 106:30093017.

11. Strauer BE, Brehm M, Zeus T, Köstering M, Hernandez A, Sorg RV, Kögler G, Wernet P: Repair of infarcted myocardium by autologous intracoronary mononuclear bone marrow cell transplantation in humans. Circulation 2002, 106:1913-1918.

12. Wollert KC, Meyer GP, Lotz J, Ringes-Lichtenberg S, Lippolt P, Breidenbach C, Fichtner S, Korte T, Hornig B, Messinger D, Arseniev L, Hertenstein B, Ganser A, Drexler H: Intracoronary autologous bone-marrow cell transfer after myocardial infarction: the BOOST randomised controlled clinical trial. Lancet 2004, 364:141-148.

13. Janssens S, Dubois C, Bogaert J, Theunissen K, Deroose C, Desmet W, Kalantzi M, Herbots L, Sinnaeve P, Dens J, Maertens J, Rademakers F, Dymarkowski S, Gheysens O, Van Cleemput J, Bormans G, Nuyts J, Belmans A, Mortelmans L, Boogaerts M, Van de Werf F: Autologous bone marrowderived stem-cell transfer in patients with ST-segment elevation myocardial infarction: double-blind, randomised controlled trial. Lancet 2006, 367:113-121.

14. Schachinger V, Erbs S, Elsasser A, Haberbosch W, Hambrecht R, Hölschermann H, Yu J, Corti R, Mathey DG, Hamm CW, Süselbeck T, Assmus B, Tonn T, Dimmeler S, Zeiher AM: REPAIR-AMI Investigators. intracoronary bone marrow-derived progenitor cells in acute myocardial infarction. $N$ Engl J Med 2006, 355:1210-1221.

15. Strauer BE, Kornowski R: Stem cell therapy in perspective. Circulation 2003, 107:929-934.

16. Sheehan FH, Bolson EL, Dodge HT, Mathey DG, Schofer J, Woo HW: Advantages and applications of the centreline method for characterizing regional ventricular function. Circulation 1986, 74:293-305. 
18. Lunde K, Solheim S, Aakhus S, Arnesen H, Abdelnoor M, Egeland T, Endresen K, llebekk A, Mangschau A, Fjeld JG, Smith HJ, Taraldsrud E, Grøgaard HK, Bjørnerheim R, Brekke M, Müller C, Hopp E, Ragnarsson A, Brinchmann JE, Forfang K: Intracoronary injection of mononuclear bone marrow cells in acute myocardial infarction. N Engl J Med 2006, 355 (12):1199-1209.

19. Seeger FH, Tonn T, Krzossok N, Zeiher AM, Dimmeler S: Cell isolation procedures matter: a comparison of different isolation protocols of bone marrow mononuclear cells used for cell therapy in patients with acute myocardial infarction. Eur Heart J 2007, 28:766-772.

20. Strauer BE, Brehm M, Zeus T, Bartsch T, Schannwell C, Antke C, Sorg RV, Kögler $G$, Wernet $P$, Müller HW, Köstering M: Regeneration of human infarcted heart muscle by intracoronary autologous bone marrow cell transplantation in chronic coronary artery disease (The IACT Study). J Am Coll Cardiol 2005, 46:1651-1658.

21. Assmus B, Honold J, Schächinger V, Britten MB, Fischer-Rasokat U, Lehmann R, Teupe C, Pistorius K, Martin H, Abolmaali ND, Tonn T, Dimmeler S, Zeiher AM: Transcoronary transplantation of progenitor cells after myocardial infarction. N Engl J Med 2006, 355:1222-1232.

22. Turan RG, Bozdag-Turan I, Ortak J, Akin I, Kische S, Schneider H, Rehders TC, Turan CH, Rauchhaus M, Kleinfeldt T, Chatterjee T, Sahin K, Nienaber CA, Ince H: Improvement of cardiac function by intra coronary freshly isolated bone marrow cells transplantation in patients with acute myocardial infarction. Circ J 2011, 75(3):546-547.

23. Turan RG, Bozdag-TI, Ortak J, Kische S, Akin I, Schneider H, Rehders TC, Turan CH, Rauchhaus M, Kleinfeldt T, Belu C, Brehm M, Yokus S, Steiner S, Sahin K, Nienhaber CA, Ince H: Improved functional activity of bone marrow derived circulating progenitor cells after intra coronary freshly isolated bone marrow cells transplantation in patients with ischemic heart disease. Stem Cell Reviews 2011, 7:646-656.

24. Turan RG, Bozdag-T I, Ortak J, Kische S, Akin I, Schneider H, Turan CH, Rehders TC, Rauchhaus M, Kleinfeldt T, Adolph E, Brehm M, Yokus S, Steiner S, Sahin K Nienhaber CA, Ince H: Improved mobilisation of the CD34+ and CD133+ bone marrow derived circulating progenitor cells by freshly isolated intracoronary bone marrow cells transplantation in patients with ischemic heart disease. Stem Cell and Development 2011, 20:1491-1501.

25. Hermann PC, Huber SL, Herrler T, von Hesler C, Andrassy J, Kevy SV, Jacobson MS, Heeschen C: Concentration of bone marrow total nucleated cells by a point-of-care device provides a high yield and preserves their functional activity. Cell Transplant 2008, 16(10):1059-1069.

26. Iba O, Matsubara H, Nozawa Y, Fujiyama S, Amano K, Mori Y, Kojima H, Iwasaka $\mathrm{T}$ : Angiogenesis by implantation of peripheral blood mononuclear cells and platelets into ischemic limbs. Circulation 2002, 106(15):2019-2025.

27. Maasberg S, Konrad I, Schürzinger K, Lorenz M, Schneider S, ZohInhoefer D, Hoppe K, Schiemann M, Kennerknecht E, Sauer S, Schulz C, Kerstan S, Rudelius M, Seidl S, Sorge F, Langer H, Peluso M, Goyal P, Vestweber D, Emambokus NR, Busch DH, Frampton J, Gawaz M: Platelets secrete stromal cell-derived factor 1 alpha and recruit bone marrow-derived progenitor cells to arterial thrombi in vivo. J Exp Med 2006, 203(5):1221-1233.

28. Dimmeler S, Burchfield J, Zeiher AM: Cell-based therapy of myocardial infarction. Arterioscler Thromb Vasc Biol 2008, 28:208-216.

29. Lipinski MJ, Biondi-Zoccai GG, Abbate A, Khianey R, Sheiban I, Bartunek J, Vanderheyden M, Kim HS, Kang HJ, Strauer BE, Vetrovec GW: Impact of intracoronary cell therapy on left ventricular function in the setting of acute myocardial infarction. J Am Coll Cardiol 2007, 50:1761-1767.

30. Choi YH, Saric T, Nasseri B, Hühn S, Van Linthout S, Hetzer R, Tschöpe C, Stamm C: Cardiac cell therapies: the next generation. Cardiovasc Ther 2011. doi:10.1111/j.1755-5922.2010.00191.

31. Jiang $Y$, Jahagirdar BN, Reinhardt RL, Schwartz RE, Keene CD, Ortiz-Gonzalez XR, Reyes M, Lenvik T, Lund T, Blackstad M, Du J, Aldrich S, Lisberg A, Low WC, Largaespada DA, Verfaillie CM: Pluripotency of mesenchymal stem cells derived from adult marrow. Nature 2002, 418:41-49.

32. Blau HM, Brazelton TR, Weimann JM: The evolving concept of a stem cell: entity or function? Cell 2001, 105:829-841.

\section{doi:10.1186/1756-0500-5-195}

Cite this article as: Bozdag-Turan et al:: Intra coronary freshly isolated bone marrow cells transplantation improve cardiac function in patients with ischemic heart disease. BMC Research Notes 2012 5:195.

\section{Submit your next manuscript to BioMed Central and take full advantage of:}

- Convenient online submission

- Thorough peer review

- No space constraints or color figure charges

- Immediate publication on acceptance

- Inclusion in PubMed, CAS, Scopus and Google Scholar

- Research which is freely available for redistribution 